\title{
Use of Web 2.0 applications in product development: an empirical study of the potential for knowledge creation and exchange in research and development
}

\author{
K.-I. Voigt ${ }^{1}$, M. Ernst ${ }^{2 *}$ \\ ${ }^{1}$ Chair of Industrial Management, University of Erlangen-Nuermberg, GERMANY \\ ${ }^{2 *}$ Chair of Industrial Management, University of Erlangen-Nuermberg, GERMANY \\ "Corresponding Author; e-mail: voigt@industriebetriebslehre.de, ernst@industriebetriebslehre.de, Tel. +49-911-5302-244/-233, Fax. +49-911-5302-238
}

\begin{abstract}
Over the past few years the common usage of the internet has dramatically changed towards the so-called Web 2.0. That means a fundamental change of the principles of creating and processing information in the internet. Companies have started to benefit from the emerging chances. Previous researches concentrate on studying of the usage of Web 2.0 tools within companies in general. But the concept of Web 2.0 contains also a great potential for the internal use of such applications, which has not been investigated yet. The potential of the internal integration of employees across several organizational units is important in particular for the process of innovation, especially in research and development. This paper examines the potential of an internal use of Web 2.0 applications for generating and sharing knowledge. An empirical study shows the status quo of the corporate use of Web 2.0 tools within companies. The study evaluates the quality of the content and the frequency of corporate use of Web 2.0 applications as well as the integration of those applications in daily business. Furthermore, the study analyzes the impact of internally used Web 2.0 applications in research and development departments of companies, especially on the emergence of innovations.
\end{abstract}

Keywords: Web 2.0, Enterprise 2.0, knowledge management, research and development (R\&D), innovation management, product development

\section{Introduction}

Because of its characteristics to bring new products to market, innovation management is a very sensitive issue concerning the competitiveness of a company (Vahs and Burmester, 2005). Recently, the so-called "Web 2.0" has become an essential part of internet usage, especially in the private sector (von Krotzfleisch et al., 2008). The resulting change of fundamental principles of editing and processing information concerning aspects like openness, exploration and community (Kranz et al., 2009) is getting more and more important for companies. Thus, Web 2.0 applications are diffusing into ventures continuously and are rapidly establishing themselves in corporate processes as well (Bilgram et al., 2008; McAfee (b), 2009). A corresponding use of such applications seems to be in particular promising in research and development (R\&D). The availability of corporate knowledge is of considerable importance for the realization of competitive advantage, not least concerning product development as being an essential part of technology and innovation management (Krause et al., 2007). In this context, Web 2.0 applications are suited in particular to support corporate project work, for example by reducing development team complexity or by further developing the corporate knowledge base, due to their characteristics concerning the linking-up of users or content (Schachner et al., 2009).

Several recent studies deal with the use of Web 2.0 applications by companies, but do not focus on product development, respectively the area of $\mathrm{R} \& \mathrm{D}$. In this paper, we evaluate the status quo of corporate use of Web 2.0 applications especially in this field. Therefore, we point out the importance of knowledge, respectively knowledge management in R\&D (Brem and Voigt, 2009). In the next step, we deduce a conceptual framework of the implementation and suitability of corporate use of Web 2.0 tools. Building on this framework, we present our findings of an empirical study evaluating the corporate use of Web 2.0 applications. 
After that, the results are discussed in detail and managerial implications are derived. The paper concludes with a short summary of the essential findings and some perspectives for further research.

\section{Importance of knowledge in product development - conceptual background}

The essential basis of competitiveness of a company is the ability of creating and implementing innovations successfully in the market (Vahs and Burmester, 2005). In this context, companies among all branches have to deal with an increased importance of time-to-market as a result of the acceleration of competition. The faster a company can realize innovations, the bigger the time lead in the market and the higher the competitiveness (Voigt, 1998; Geulen, 2006). As a consequence, corporate activities have to be focused consequently on the continuous development and placement of market-conform innovations. Besides, empirical studies from practice show that companies, whose innovation processes are organized effectively and efficiently, are more successful than companies without well structured innovation processes (Reichart and Reichart, 2006).

In practice, product development is marked by a geographical, temporal and topical decoupling. As a result of globalization, the development of new products occurs more and more at different locations and in different time-slots. Additionally, the increasing complexity of the development task demands cooperation and collaboration in interdisciplinary (project) teams (Berkhout et al., 2006; Borchert and Hagenhoff, 2004). To establish innovation successfully in the market, companies are increasingly forced to conduct their innovation tasks within networks (Borchert and Hagenhoff, 2004).

Therefore the opening of the innovation processes outwards - for example for the inspiration for new ideas - is as important as the freedom for employees to realize their ideas and to share their knowledge (Ganswindt, 2006). Only the connection of the knowledge of all employees involved in order to foster a common understanding of a new idea enables the emergence of innovations (Neyer et al., 2008). Knowledge and also the exchange of knowledge do represent potential sources of competitive advantages (Bach and Homp, 1998; Boos et al., 2008). Through the active use of the once financed knowledge acquisition or the multi-usage of knowledge, an added value for the company can be created (Reinhold and Michel, 2007). As a result of the usage or further development of the existing knowledge for the given task - in the context of new product development - the existing capacities can be focused on the development of new products (Krause et al., 2007). The sooner knowledge is available along the product development process, the more efficient one can react on changes of the task (Ehrlenspiel, 2005). That means that for product development, the continuous availability of knowledge is of essential importance. Because of that, the management of corporate knowledge does also play a central role. The main challenges are to exploit, to structure, to retrieve and to make available knowledge concerning either products or processes and so exploit unused potentials. Thus, the process of product development can also be seen as a process of knowledge creation (Madhavan and Grover, 1998).

In recent scientific discussions, there is a gap concerning operational instruments of managing innovation networks, which support an effective and efficient achievement of strategic goals (Borchert and Hagenhoff, 2004). So tools are needed, which are able to reverse the geographical, temporal and topical decoupling of product development and support in the same way the linkingup of employees and content. Our paper presents the characteristics of Web 2.0 applications and shows their inherent potential to close or at least to reduce this gap.

\section{Web 2.0 within companies}

The term "Web 2.0" is not clearly defined and classified in scientific discussion (Langham, 2007). According to current scientific considerations, there are several points of view concerning the distinction of terms. As a consequence the distinction between single applications is not consistent in classification and definition (Bohl and Manouchehri, 2008). Nevertheless, the change in the way of interacting and communicating amongst users can be considered as a common aspect of all these different points of view (Cook, 2008). This can be summarized with the catchphrase "the internet to join" (Hage, 2006). Thus, Web 2.0 tools denote web-based applications, which do not contain a centralized administration and are characterized in particular through the interaction and participation of users (Tapscott and Williams, 2006; Beck, 2007; McAfee (b), 2009). Moreover, those tools encourage a so-called "many-to-many" communication (Gouthier and Hippner, 2008) and change the way of creating, organizing, searching and distributing of information (Hirsch et al., 2009).

Since the end of 2006, the term Web 2.0 has increasingly been used in conjunction with internal corporate processes, concerning internal collaboration and communication regarding especially the exchange of knowledge (N.N.(a), 2006). In general, in current literature, the term "enterprise 2.0" describes the use of Web 2.0 applications within companies (McAfee, 2006). Thus, this term summarizes applications from the internet, which are - due to diffusion processes from private to corporate use - increasingly applied by companies (Lochmaier, 2007). Accordingly, the term “enterprise 2.0" represents different concepts of a new kind of collaboration, fostered by the networking of employees and converted by technological components of Web 2.0 (McAfee, 2006; Zimmermann, 2007; McAfee (b), 2009).

This trend is confirmed by several recent studies: In a study of BITKOM ${ }^{1}$ in 2008 almost half of the surveyed companies indicated that they had been facing up with the topic Web 2.0 since 2006/2007 (Weber, 2008). According to a McKinsey study

\footnotetext{
${ }^{1}$ Federal Association for Information Technology, Telecommunications and New Media
} 
from 2009, 69\% of the evaluated ventures are able to register at least one measureable success of their business activity through the use of Web 2.0 (Bughin et al., 2009). Main goal of these enterprises is supporting business activities by the work- or processoriented provision of knowledge (N.N.(b), 2006). In the long run, companies try to support the linking-up between employees (involved) as well as the linking-up of the content produced by them. Thereby, companies aim to supply their staff with the right piece of information at the right time (Bächle, 2008). The three main aspects that contribute to a maximum of benefit pointed out by the companies evaluated in 2009, is the accelerated access to knowledge (68\%), the reduction of communication costs (54\%) and the possibilities of faster getting in contact with corporate experts (43\%) (Bughin et al., 2009).

Figure 1 shows an overview of different applications of the Web 2.0. For the analyses in this paper, we have chosen those applications, which have - according to recent literature on the one hand (for example Koch/Richter 2007, Back et al., 2008, Weber, 2008) and to a qualitative pre-research of internal use of Web 2.0 (Ernst, 2009) on the other hand - the highest potential to support product development.

Social Bookmarking Prediction Markets

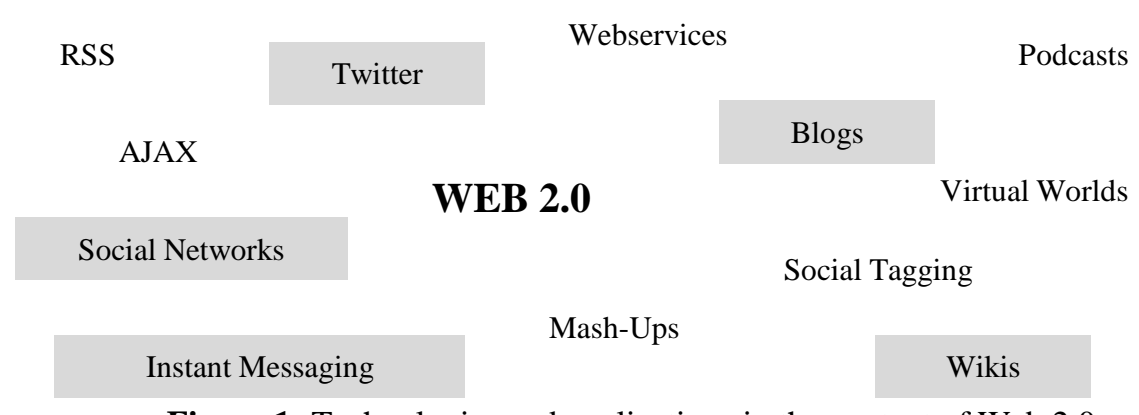

Figure 1: Technologies and applications in the context of Web 2.0

However, the studies mentioned above do focus on the use of Web 2.0 applications by companies in general and do not distinguish between the business areas, in which these tools are used or whether it is an external or internal use or a combination of both across company boundaries (for example Bughin et al., 2008). Given the particular suitability of Web 2.0 applications in product development, we evaluate in this study the internal use of Web 2.0 tools within companies especially in product development in order to close the existing gap in research and to contribute to the scientific discussion. Because the process of product development can hardly be isolated, we have focused our analyses on the R\&D department being linked closely to the process of product development itself.

\section{Potentials of Web 2.0 applications}

\subsection{Overview}

Through the increasing integration of Web 2.0 applications into corporate processes, the cross-departmental and even the crossventure integration of employees in the context of knowledge management can be supported in order to encourage the genesis of innovations (Lattemann et al., 2009). The classic role allocation of knowledge management between authors and the target group of this kind of systems (Komus and Wauch, 2008) has been abolished due to Web 2.0 applications (Grossmann and McCarthy, 2007). In an ideal matter, a corporate-wide or even network-wide transfer of knowledge can occur though the disposal of knowledge as well as the consumption of knowledge by every employee involved (Carr, 2004; Gölz, 2007). By a recombination of subject-specific knowledge of employees of different organizational departments or even different network nodes within collaboration and communication processes, a crucial contribution to the success of innovation can be achieved (Kranz et al., 2009) - stimulated by the so-called "power of the group" (Hideyuki, 2007, p. 65).

Structured content constitutes the basis of navigation in and provision of knowledge (Sandkuhl, 2005). Web 2.0 applications are especially appropriate for structuring content through the possibilities of linking unstructured data - as they do occur in particular in early stages of product development for example as a result of unstructured search in idea creation (Koen et al., 2002). An internal use of appropriate Web 2.0 tools can offer several potentials for integrating organizational units of companies. As a result of the social characteristics of these tools, they support the creation and expansion of the user-networks (Gouthier and Hippner, 2008; Komus and Wauch, 2008).

\subsection{Characterization of Applications}

The selected Web 2.0 applications (Figure 1) can be categorized by reference to several criteria. Besides the creation of content, the possibility of editing existing content by other users is an important characteristic concerning the evaluation of different tools (Beck, 2007). Furthermore, it is also important, that content can be retrieved user-independently. Another aspect is the linking-up of users - e.g. employees within a company as well as employees between networked ventures - as well as the linking-up of 
content as one of the central ideas of Web 2.0. Taken all together, these four aspects do have a positive influence on the utilization of corporate knowledge. Figure 3 shows a comparison of the selected applications.

Editing of content, which has been provided by other users, is very easy in Wikis (McAfee (a), 2009). In Blogs - because of the assignment to one single author - editing is only possible in an indirect way through comments. Concerning Social Networks this effect can only be realized by the creation of additional groups within the application, e.g. in a forum. Content in Instant Messaging or Twitter cannot be edited by other users, so that Wikis are the only class of applications, in which this is possible in an easy way. Content can be retrieved in case of Wikis, Blogs or Social Networks or at least Twitter either by the use of a tagcloud or by the use of included search mechanisms. Within Instant Messaging, there is no way to retrieve content and even storing content is only possible with considerable effort (Koch and Richter, 2007). The linking-up of users via Blogs can happen through comments (trackbacks, pingbacks or permalinks) or responding Blog posts. Concerning the operating principle of Wikis, an assignment to the respective reference person of certain topics is not as intuitive as in Blogs - the same as it is in Instant Messaging applications. Within Social Networks and Twitter, the linking-up of the users occurs by the use of the application by fostering the personal, e.g. user-specific network, so that these tools are suited best for connecting people (Koch and Richter, 2007). Concerning the content of Social Network applications, linking-up is not possible in all of them. Instant Messaging is not suited, because content is not easy to store and communication is the main focus. Within Social Networks, the main goal is to link people together and so the linking-up of content is mostly bound to individuals. Concerning Blogs and Twitter, content can be linked-up in a similar way as authors referring to previous entries. Wikis are suited best to link-up content due to the use of links between different Wiki articles via key-words (Alby, 2007). Through an internal use for example in project teams, versioning of several documents with several authors can be handled easily (Newman and Thomas, 2009).

\begin{tabular}{l|c|c|c|c|} 
& $\begin{array}{c}\text { Editing of } \\
\text { Content }\end{array}$ & $\begin{array}{c}\text { Retrival of } \\
\text { Content }\end{array}$ & $\begin{array}{c}\text { Linking-up of } \\
\text { Users }\end{array}$ & $\begin{array}{c}\text { Linking-up of } \\
\text { Content }\end{array}$ \\
\hline Blogs & $\mathrm{O}$ & $\mathrm{X}$ & $\mathrm{X}$ & $\mathrm{X}$ \\
\hline Wikis & $\mathrm{X}$ & $\mathrm{X}$ & $\mathrm{O}$ & $\mathrm{X}$ \\
\hline Social Network & $\mathrm{O}$ & $\mathrm{X}$ & $\mathrm{X}$ & $\mathrm{O}$ \\
\hline Instant Messaging & - & - & $\mathrm{O}$ & - \\
\hline Twitter & - & $\mathrm{O}$ & $\mathrm{X}$ & $\mathrm{X}$
\end{tabular}

Legend: $\mathrm{X}$ = well suited, $\mathrm{O}$ = average suited, - = not suited

Figure 2: Evaluation of the selected Web 2.0 applications

Taking everything into consideration, Web 2.0 applications contain several potentials to support corporate knowledge management. So these tools can support research in teams or with partners (Bullinger et al., 2010) and so potentially encourage the realization of innovations. The use of Web 2.0 applications in order to integrate knowledge and therefore employees seems particularly appropriate within the context of R\&D. In the following, we evaluate the status quo of the internal use of Web 2.0 tools within companies in their R\&D department. It should be examined, if the potentials mentioned above have already been realized in companies. Therefore, we try to answer the question of how Web 2.0 applications are used in daily business of product development. Furthermore, we evaluate the content of the applications and analyze how the content is judged and assessed by the respondents.

\section{Empirical Evaluation}

\subsection{Research Design}

The aim of this paper is to close the gap in existing studies, which do not deal with the internal use of Web 2.0 applications in R\&D. We investigate in which ways employees can be supported through the use of Web 2.0 tools in linking-up with others in order to collaborate in knowledge creation and exchange.

Therefore, in a first step, we have conducted an explorative, qualitative expert survey in order to find out, what kind of peculiarities are to be taken into consideration concerning corporate implementation and use of Web 2.0 applications. For that reason, we have conducted 13 interviews with experts who have to deal with this topic being in an appropriate management position. The interviews have been conducted in software and industrial enterprises. Software companies have been chosen because they can be seen as pioneers concerning the internal use of such applications. Industrial companies have been chosen 
because of the particular potential of support by Web 2.0 tools: their product structures being characterized by high complexity lead to special requirements for product development concerning interdisciplinary or development team complexity. Based on the findings of this pre-investigation (Ernst, 2009), the design of the further research has been developed.

\subsection{Methodology}

For the implementation of the following quantitative research, an online questionnaire has been designed. The development procedure of this questionnaire can be separated into five steps. First, it had to be decided about the types and content of the single questions and then they have been formulated in detail. In the third step, the order of the questions and so the structure and final layout of the questionnaire have been determined. In the last step, several pre-tests had been conducted (Wilson, 2003) and the whole questionnaire has been modified and finally finished (Homburg and Krohmer, 2006).

The standardized questionnaire has contained the same questions in the same order with the same possible answers for all participants (Seipel and Rieker, 2003). The questionnaire has contained apart from the introduction three blocks of questions. The first section served the capturing of data concerning the company of the participant and the deployed Web 2.0 applications. In the second section there have been questions about the use of the offered Web 2.0 tools in daily business and in the last section, there have been questions about the evaluation of an explicit contribution of the applications to innovation management.

The questionnaire has consisted of objective answering questions of properties (Böhler, 1992) and subjective questions of attitudes or opinions (Berndt, 1996; Berekoven et al., 2001). Questions of properties serve for the description of important characteristics of the examination unit (for example branch or size of enterprise) or its functional areas (Böhler, 1992). Questions of attitudes or questions of opinions identify on the one hand a common evaluation of areas of interest and on the other hand the implementation of these areas in the surveyed company (Berndt, 1996; Berekoven et al., 2001).

Berekoven et al. propose the use of rating scales to measure attitudes or opinions because of their simple application (Berekoven et al., 2001). The main objective of scaling is to make theoretical aspects quantifiable, which are not observable directly. In order not to overcharge the ability of discrimination of the respondents, there should be predefined four to seven stages. The addition of alternative categories ("I can't really say", "no answer") is not seen as mandatory by Berekoven et al. (Berekoven et al., 2001). Besides rating scales, likert scales have been used within the survey in order measure attitudes of the participants ${ }^{2}$ (Albers, 2007).

\section{Results}

We have asked in total 497 people from companies in Germany out of different branches to participate in the survey, on which this paper is based on, in autumn 2009. We have contacted the participants via internet in a personal mailing. As selection criteria we have used the individual work experience in dealing with Web 2.0 applications on the one hand and on the other hand we have chosen the professional work of the participants in the area of Enterprise 2.0, Web 2.0, product development, project management, technology management or innovation management for selection. The participation rate has reached $45.8 \%$ with 174 participants and a termination rate of $23.2 \%$.

In total, companies of all magnitudes have been questioned ( $\mathrm{n}=141)$, whereby the majority of the participants (39.3\%) worked in companies with one to 100 employees during the past business year. 15.6\% worked in companies with 101 to 500 employees and $31.2 \%$ in companies with more than 1,000 employees.

Concerning the Web 2.0 applications being used, we state that within the surveyed companies $(\mathrm{n}=116)$ Wikis are mostly used (84.5\%) followed up by Instant Messaging applications (76.7\%), Blogs (65.5\%) and Social Networks (51.7\%). Twitter or a comparable tool have already been in use within $37.1 \%$ of the surveyed companies. These results go in hand with the assumptions derived from our previous qualitative survey.

The investigated Web 2.0 applications are used within the surveyed companies in several departments ( $\mathrm{n}=109)$. Among the participants of the study, Wikis are mostly used in R\&D (R\&D, 53.8\%). The second most common use in the R\&D sector concerns Blogs (32.3\%) and Instant Messaging tools (29.0\%) followed up by Twitter respectively comparable tools (24.1\%) and finally Social Networks (23.9\%). As some authors in recent literature suggest, the use of Web 2.0 applications in other departments is of subsidiary importance (Figure 3).

\footnotetext{
${ }^{2}$ Attitude is measured through several statements, which are to be evaluated by the participants in a continuum reaching from especially positive to especially negative, for example „applies completely“ to „doesn’t apply at all“ (Albers, 2007).
} 


\begin{tabular}{lcccccc}
\hline & Blogs & Wikis & $\begin{array}{c}\text { Social } \\
\text { Network }\end{array}$ & $\begin{array}{c}\text { Instant } \\
\text { Messaging }\end{array}$ & Twitter \\
\hline overall & mentions & 62 & 80 & 46 & 69 & 29 \\
& $\%$ & $56.9 \%$ & $73.4 \%$ & $42.2 \%$ & $63.3 \%$ & $26.6 \%$ \\
\hline R\&D & mentions & 25 & 43 & 11 & 20 & 7 \\
& $\%$ & $40.3 \%$ & $53.8 \%$ & $23.9 \%$ & $29.0 \%$ & $24.1 \%$ \\
\hline
\end{tabular}

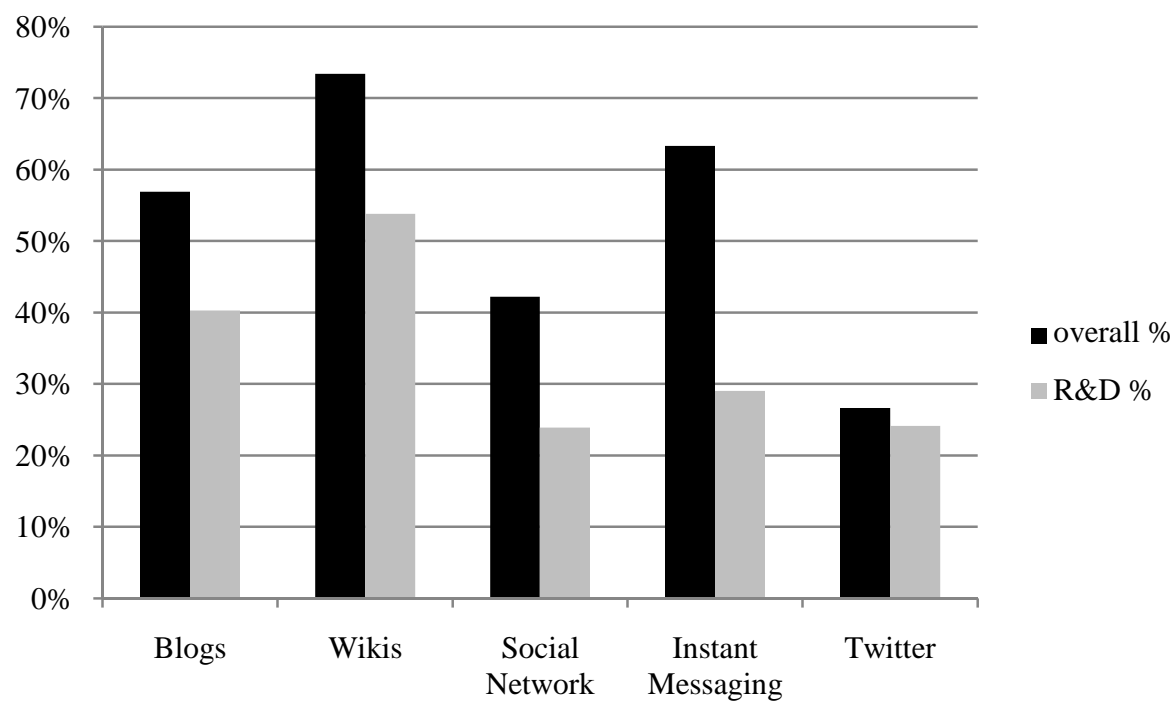

Figure 3: Distribution of different Web 2.0 applications

The distribution of the use of the applications in R\&D is similar to the distribution of the use among the rest of the corporate departments, but the frequency of use of the single tools is distributed towards some single items (Figure 4). In $44.0 \%$ of the cases in R\&D, Blogs are only used occasionally. In contrast, Wikis are more often used frequently (30.3\%) or very frequently (23.3\%) in daily business. In total, more than three-quarter of the respondents are using Social Networks occasionally (27.3\%), frequently (27.3\%) or very frequently (36.3\%). Instant Messaging is used very frequently by $60.6 \%$ of the respondents in R\&D. Twitter or comparable applications are used in equal parts occasionally, frequently or very frequently with $28.6 \%$ each.

How often do you use the offered applications in daily business?

\begin{tabular}{|c|c|c|c|c|c|c|c|}
\hline & & never & seldom & sometimes & frequently & very frequently & $\mathbf{n}$ \\
\hline \multicolumn{8}{|l|}{ Blogs } \\
\hline & overall & $8.7 \%$ & $15.9 \%$ & $34.8 \%$ & $26.1 \%$ & $14.5 \%$ & 69 \\
\hline & in $\mathrm{R} \& \mathrm{D}$ & $8.0 \%$ & $8.0 \%$ & $44.0 \%$ & $32.0 \%$ & $8.0 \%$ & 25 \\
\hline \multicolumn{8}{|l|}{ Wikis } \\
\hline & overall & $2.3 \%$ & $14.6 \%$ & $23.6 \%$ & $29.2 \%$ & $30.3 \%$ & 89 \\
\hline & in $\mathrm{R} \& \mathrm{D}$ & $4.7 \%$ & $16.3 \%$ & $25.6 \%$ & $30.2 \%$ & $23.3 \%$ & 43 \\
\hline \multicolumn{8}{|c|}{ Social Network } \\
\hline & overall & $1.9 \%$ & $9.4 \%$ & $20.8 \%$ & $24.5 \%$ & $34.4 \%$ & 53 \\
\hline & in $\mathrm{R} \& \mathrm{D}$ & $0.0 \%$ & $9.1 \%$ & $27.3 \%$ & $27.3 \%$ & $36.4 \%$ & 11 \\
\hline \multicolumn{8}{|c|}{ Instant Messaging } \\
\hline & overall & $1.2 \%$ & $9.8 \%$ & $9.8 \%$ & $18.3 \%$ & $61.0 \%$ & 82 \\
\hline & in $\mathrm{R} \& \mathrm{D}$ & $0.0 \%$ & $15.0 \%$ & $15.0 \%$ & $10.0 \%$ & $60.0 \%$ & 20 \\
\hline \multicolumn{8}{|c|}{$\overline{\text { Twitter }}$} \\
\hline & overall & $13.2 \%$ & $10.5 \%$ & $23.7 \%$ & $26.3 \%$ & $26.3 \%$ & 38 \\
\hline & in $\mathrm{R} \& \mathrm{D}$ & $0.0 \%$ & $14.3 \%$ & $28.6 \%$ & $28.6 \%$ & $28.6 \%$ & 7 \\
\hline
\end{tabular}

Figure 4: Frequency of corporate use of Web 2.0 applications in R\&D 
Besides the frequency of the use of Web 2.0 applications, the associated objectives of the companies respectively the users are of great importance. The collection of knowledge is mostly connected with Blogs, Wikis and Twitter. Concerning the generation of knowledge, the respondents assign the highest potential to Twitter and Blogs. To bring in ideas into corporate processes and to develop them further, Social Networks are considered to be most target-aimed by the respondents (Figure 5).

The applications allow the collection of knowledge.

Through the applications knowledge becomes more dynamic and relevant.

The applications serve the set-up of a reference book such as a glossary.

indifferent

true

completely true

The applications are an instrument to create new ideas.

The applications are an instrument which allows me to participate in the further development of my colleagues' ideas.

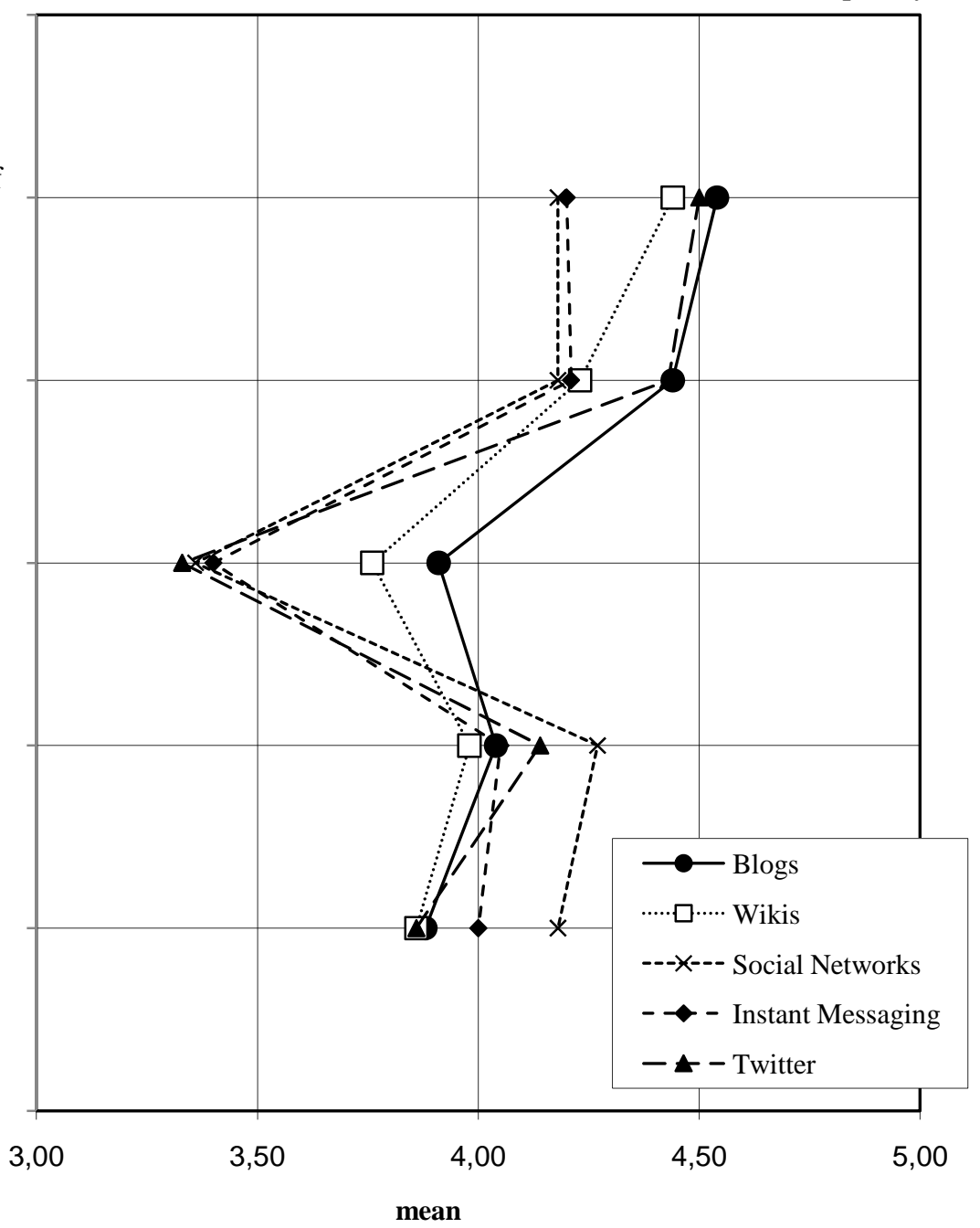

$\mathrm{n}_{\text {Blogs }}=25, \mathrm{n}_{\text {Wikis }}=43, \mathrm{n}_{\text {SocialNetworks }}=11, \mathrm{n}_{\text {InstantMessaging }}=20, \mathrm{n}_{\text {Twitter }}=7$

5-step scale from „does not fit at all“ (1) to „completely true“ (5)

Figure 5: Objectives associated with the corporate use of particular Web 2.0 applications

The duration since Web 2.0 applications have been used within companies could possibly have an influence on the frequency, the tools are used in daily business. The respondents had to answer two questions concerning this topic: On the one hand, the frequency of use has been questioned, on the other hand, we have asked for the time frame since the offered applications have been deployed within the company. In order to analyze these connections and to draw robust conclusions, an originally five-step scale has been reduced into a three-step scale. Thus we can show that in R\&D Web 2.0 applications have been most frequently used since two to three years. Thereby most of the respondents are using them occasionally or frequently in daily business (32.6\% each). If Web 2.0 applications have been used since four or more years within the company, most of the respondents are using them very frequently in daily business (Figure 6). 
How often do you use the applications in daily business?
Since when have the mentioned applications been used in your company?

\begin{tabular}{l|cccc}
\hline & $\begin{array}{c}\text { since less } \\
\text { than/exactly } \\
\text { 1 year }\end{array}$ & $\begin{array}{c}\text { since 2 or 3 } \\
\text { years }\end{array}$ & $\begin{array}{c}\text { since at least 4 } \\
\text { years }\end{array}$ & n \\
\hline never & $0.0 \%$ & $9.3 \%$ & $0.0 \%$ \\
seldom & $32.4 \%$ & $4.7 \%$ & $3.2 \%$ & \\
occasionally & $23.5 \%$ & $32.6 \%$ & $22.6 \%$ \\
frequently & $17.6 \%$ & $32.6 \%$ & $29.0 \%$ & \\
very frequently & $26.5 \%$ & $20.9 \%$ & $45.2 \%$ & 106 \\
\hline
\end{tabular}

Figure 6: Frequency of use of Web 2.0 applications depending on the duration of corporate use in R\&D

This frequency is mirrored in particular in the use of Wikis in R\&D (Figure 7). If Wikis have been used since four or more years, in most of the surveyed companies they are used very frequently. But even after two to three years of corporate use of Wikis, they are already frequently in use (36.8\%). An analysis of the use of the rest of the considered applications depending on the duration of use is not significant because of the poor database and is therefore not regarded further.

\begin{tabular}{|c|c|c|c|c|}
\hline \multirow[t]{2}{*}{$\begin{array}{l}\text { How often do you use the applications in } \\
\text { daily business? }\end{array}$} & \multicolumn{4}{|c|}{$\begin{array}{c}\text { Since when have the mentioned applications been } \\
\text { used in your company? }\end{array}$} \\
\hline & $\begin{array}{c}\text { since less } \\
\text { than/exactly } \\
1 \text { year }\end{array}$ & $\begin{array}{c}\text { since } 2 \text { or } 3 \\
\text { years }\end{array}$ & $\begin{array}{c}\text { since at least } 4 \\
\text { years }\end{array}$ & $\mathbf{n}$ \\
\hline never & $0.0 \%$ & $10.5 \%$ & $0.0 \%$ & \\
\hline seldom & $45.5 \%$ & $10.5 \%$ & $0.0 \%$ & \\
\hline occasionally & $27.3 \%$ & $26.3 \%$ & $23.1 \%$ & \\
\hline frequently & $9.1 \%$ & $36.8 \%$ & $38.5 \%$ & \\
\hline very frequently & $18.2 \%$ & $15.8 \%$ & $38.5 \%$ & 43 \\
\hline
\end{tabular}

Figure 7: Frequency of use of Wikis depending on the duration of corporate use in R\&D

In R\&D, content distributed by Web 2.0 applications is mainly for informational purpose in the meaning of a reference book e.g. a glossary (Figure 8). This is especially the case of the use of Blogs (50.0\%), Wikis (31.6\%) and Social Networks (40.0\%). Communication by Instant Messaging is seen as essential for daily business respectively for the maintenance of business activity by most of the respondents (47.4\%). Content, which is exchanged in Twitter, is mainly project specific (40.0\%).

The content is mainly...

\begin{tabular}{lcccc}
\hline & $\begin{array}{c}\text { necessary for daily } \\
\text { business/ the } \\
\text { maintenance of } \\
\text { business activity }\end{array}$ & $\begin{array}{c}\text { purely informative } \\
\text { such as a glossary }\end{array}$ & $\begin{array}{c}\text { specific for certain } \\
\text { projects }\end{array}$ & $\begin{array}{c}\text { All the answers are } \\
\text { true. }\end{array}$ \\
\hline Blogs & $4.5 \%$ & $50.0 \%$ & $13.6 \%$ & $31.8 \%$ \\
\hline Wikis & $7.9 \%$ & $31.6 \%$ & $21.1 \%$ & $39.5 \%$ \\
\hline Social Network & $10.0 \%$ & $40.0 \%$ & $30.0 \%$ & $20.0 \%$ \\
\hline Instant Messaging & $47.4 \%$ & $21.1 \%$ & $26.3 \%$ & $5.3 \%$ \\
\hline Twitter & $20.0 \%$ & $40.0 \%$ & $20.0 \%$ \\
\hline
\end{tabular}

Figure 8: Content within different Web 2.0 applications in R\&D 
Concerning the quality of the content in Web 2.0 applications, $27.3 \%$ of the respondents report that it was very high in Blogs. In contrast to that, $40.9 \%$ state that quality varies according to specific use cases or information needs of the user. In the case of Wikis, users are much more convinced of the quality of the content. In our survey, 30.8\% report content of very high quality and $28.2 \%$ content with high quality in their corporate Wikis. Only $15.4 \%$ experience different quality depending on specific use cases. The quality of content communicated through Social Networks is classified average or depending on specific use cases by $40.0 \%$ of the respondents each. In accordance to that, the quality of content in Instant Messaging tools is equally seen as average or depending on specific use cases $(26.3 \%$ each) or even high $(21.1 \%)$. The quality of content within Twitter or comparable applications is assessed high by $40.0 \%$ of the respondents. This shows that content, which is distributed or exchanged via Wikis in R\&D, does have the highest quality perception (Figure 9).

In order to ensure this kind of quality, the surveyed companies have taken different measurements. The most frequent stated measurement $(78.2 \%)$ is the responsibility of the authoring employee to ensure the quality of content. Self-cleaning properties of the corporate community (45.5\%) play also an important role in this context as well as the appointment of an employee, who is responsible for certain areas of content, for example a so-called "Wiki gardener" (34.5\%). Other measurements like editorial teams or the evaluation of content by users are of little significance among the used applications.

The quality of the content within the applications is...

\begin{tabular}{|c|c|c|c|c|c|c|c|}
\hline & very low & low & average & high & very high & $\begin{array}{l}\text { depends on use case/ } \\
\text { need of information }\end{array}$ & $\mathbf{n}$ \\
\hline \multicolumn{8}{|l|}{$\overline{\text { Blogs }}$} \\
\hline & $4.5 \%$ & $4.5 \%$ & $9.1 \%$ & $27.3 \%$ & $13.6 \%$ & $40.9 \%$ & 22 \\
\hline \multicolumn{8}{|l|}{ Wikis } \\
\hline & $5.1 \%$ & $5.1 \%$ & $15.4 \%$ & $28.2 \%$ & $30.8 \%$ & $15.4 \%$ & 39 \\
\hline \multicolumn{8}{|l|}{ Social Network } \\
\hline & $0.0 \%$ & $0.0 \%$ & $40.0 \%$ & $10.0 \%$ & $10.0 \%$ & $40.0 \%$ & 10 \\
\hline \multicolumn{8}{|l|}{ Instant Messaging } \\
\hline & $5.3 \%$ & $5.3 \%$ & $26.3 \%$ & $21.1 \%$ & $15.8 \%$ & $26.3 \%$ & 19 \\
\hline \multicolumn{8}{|l|}{ Twitter } \\
\hline & $0.0 \%$ & $20.0 \%$ & $20.0 \%$ & $40.0 \%$ & $0.0 \%$ & $20.0 \%$ & 5 \\
\hline
\end{tabular}

Figure 9: Evaluation of quality of the content within Web 2.0 applications

Asked for the liability of the contained content, respondents state the following: In case of $37.7 \%$ of the surveyed companies, the content is fully liable. $18.9 \%$ of the respondents report that content is liable after consulting the author and $3.8 \%$ have to talk to a superior. In $22.6 \%$ of the cases Web 2.0 applications are used in R\&D, content is only informative but never liable. But also $17.0 \%$ of the respondents have not yet considered liability at all.

Through an enhanced use of Web 2.0 applications, established applications could possibly be substituted. In our survey, most of the respondents answer that there is no substitution (32.7\%), but that Web 2.0 applications are a useful addition to existing applications. Nevertheless, $26.9 \%$ are of the opinion that mainly telephone calls and e-mail applications are substituted by the use of Web 2.0 tools. Others point out that it is rather e-mail applications (17.3\%) or rather telephone calls (13.5\%), which are substituted by Web 2.0 tools (Figure 10). 
Does the use of Web 2.0 applications lead to a substitution of existing and established applications within your company respectively within your personal daily business?

\begin{tabular}{lr}
\hline No, Web 2.0 applications are a useful addition to existing applications. & $\mathrm{n}=52$ \\
\hline Yes, telehone calls and e-mails have been substituted. & $32.7 \%$ \\
\hline Yes, mainly e-mails have been substituted. & $26.9 \%$ \\
\hline Yes, e-mails and MS-Office applications have been substituted. & $17.3 \%$ \\
\hline Yes, mainly phone calls have been substituted. & $15.4 \%$ \\
\hline Yes, e-mails and MS-Office applications have been substituted. & $13.5 \%$ \\
\hline Yes, mainly MS-Office applications have been substituted. & $3.8 \%$ \\
\hline Yes, e-mails and MS-Office applications and phone calls have been substituted. & $9.6 \%$ \\
\hline Another kind of substitution can be observed. & $9.6 \%$ \\
\hline No, there is no relation between Web 2.0 applications and existing applications. & $9.6 \%$ \\
\hline
\end{tabular}

Figure 10: Substitution of established applications by the use of Web 2.0 applications

Scientific literature suggests - as we show above - that in particular in R\&D the use of Web 2.0 has a positive influence on the generation of new ideas. In our survey, 33.3\% of the respondents, who are using Blogs in $R \& D(n=55)$, support this statement. In $14.3 \%$ of the cases, a considerable increase in the number of new ideas can be observed. In contrast to that, $28.6 \%$ of the respondents cannot measure any changes in the number of new ideas.

This picture remains the same regarding every single application. In $41.7 \%$ of the cases of using Wikis, the number of generated ideas increased, but simultaneously $33.3 \%$ of the respondents report that there is no change in this number. The use of Instant Messaging has led to more ideas in 33.3\% of the cases, but also $27.8 \%$ do not support this proposition and $20.0 \%$ cannot make a statement at all. Employees of companies, where Twitter is used in R\&D, report mostly no change in the number of ideas (50.0\%) followed up by $25.0 \%$ who record a very strong increase of newly generated ideas. If Social Networks are used in R\&D, $40.0 \%$ of the respondents state that the number of new ideas has increased by the use of Web 2.0 applications and even $30.0 \%$ think that there has been a very strong increase (Figure 11).

Through the use of Web 2.0 applications the number of new ideas has been...

\begin{tabular}{|c|c|c|c|c|c|c|c|}
\hline & $\begin{array}{c}\text { extremely } \\
\text { reduced }\end{array}$ & reduced & uninfluenced & increased & $\begin{array}{l}\text { significantly } \\
\text { increased }\end{array}$ & $\begin{array}{c}\text { I cannot } \\
\text { answer this } \\
\text { question. }\end{array}$ & $\mathbf{n}$ \\
\hline \multicolumn{8}{|l|}{$\overline{B \log s}$} \\
\hline & $0.0 \%$ & $4.8 \%$ & $28.6 \%$ & $33.3 \%$ & $14.3 \%$ & $19.0 \%$ & 21 \\
\hline \multicolumn{8}{|l|}{ Wikis } \\
\hline & $2.8 \%$ & $0.0 \%$ & $33.3 \%$ & $41.7 \%$ & $2.8 \%$ & $19.4 \%$ & 36 \\
\hline \multicolumn{8}{|l|}{ Social Network } \\
\hline & $0.0 \%$ & $0.0 \%$ & $10.0 \%$ & $40.0 \%$ & $30.0 \%$ & $20.0 \%$ & 10 \\
\hline \multicolumn{8}{|l|}{ Instant Messaging } \\
\hline & $0.0 \%$ & $5.6 \%$ & $27.8 \%$ & $33.3 \%$ & $5.6 \%$ & $27.8 \%$ & 18 \\
\hline \multicolumn{8}{|l|}{ Twitter } \\
\hline & $0.0 \%$ & $0.0 \%$ & $50.0 \%$ & $0.0 \%$ & $25.0 \%$ & $25.0 \%$ & 4 \\
\hline
\end{tabular}

Figure 11: Change in number of new ideas due to corporate use of Web 2.0 applications 
Concerning the discussion of new ideas within the company, half of the respondents, who are using Blogs in R\&D (52.4\%), are of the opinion that the discussion of new ideas has become more transparent respectively enforced and/or more controversial due to corporate use of Blogs (Figure 12). The respondents using Wikis support this statement in $47.2 \%$ of the cases and so do $50.0 \%$ of the ones, who are using Social Networks. Concerning the use of Twitter in R\&D, the respondents think that the discussion of new ideas has intensified (50.0\%), respectively has been made possible at all (50.0\%).

In contrast to that, the use of the other applications does not affect the discussion of new ideas. Most of the respondents (38.9\%) state that the use of Instant Messaging has not led to a change in the way, new ideas are discussed.

Through the application the discussion of new ideas has been...

\begin{tabular}{|c|c|c|c|c|c|c|}
\hline & $\begin{array}{c}\text { made more } \\
\text { difficult }\end{array}$ & uninfluenced & $\begin{array}{c}\text { more } \\
\text { transparent, } \\
\text { more intense } \\
\text { and/or more } \\
\text { controversial }\end{array}$ & $\begin{array}{c}\text { made possible } \\
\text { at all }\end{array}$ & $\begin{array}{l}\text { I cannot answer } \\
\text { this question. }\end{array}$ & $\mathbf{n}$ \\
\hline \multicolumn{7}{|l|}{$\overline{B \log s}$} \\
\hline & $4.8 \%$ & $23.8 \%$ & $52.4 \%$ & $4.8 \%$ & $14.3 \%$ & 21 \\
\hline \multicolumn{7}{|l|}{ Wikis } \\
\hline & $2.8 \%$ & $19.4 \%$ & $47.2 \%$ & $8.3 \%$ & $22.2 \%$ & 36 \\
\hline \multicolumn{7}{|l|}{ Social Network } \\
\hline & $0.0 \%$ & $20.0 \%$ & $50.0 \%$ & $20.0 \%$ & $10.0 \%$ & 10 \\
\hline \multicolumn{7}{|l|}{ Instant Messaging } \\
\hline & $0.0 \%$ & $38.9 \%$ & $33.3 \%$ & $11.1 \%$ & $16.7 \%$ & 18 \\
\hline \multicolumn{7}{|l|}{ Twitter } \\
\hline & $0.0 \%$ & $0.0 \%$ & $50.0 \%$ & $50.0 \%$ & $0.0 \%$ & 4 \\
\hline
\end{tabular}

Figure 12: Change in the way of discussing new ideas due to the corporate use of Web 2.0 applications

As last question, we evaluated the assessment of the respondents concerning the impact of the corporate use of Web 2.0 applications on the speed of innovation of their company (n=49). 46.9\% of the respondents, who use at least one Web 2.0 tool in $\mathrm{R} \& \mathrm{D}$, state that the speed of innovation has increased due to the use of Web 2.0 applications within their company. 30.6\% report that there has not been any change of the speed of innovation and $20.4 \%$ cannot make a statement about this topic.

\section{Discussion and Managerial Implications}

The empirical results show that Web 2.0 applications can absolutely be used to support product development. At first among others, this can be deduced from the frequency of the use of Web 2.0 applications in R\&D in comparison to other corporate departments. Nevertheless, Web 2.0 applications are used in a disproportionally frequent way among smaller or large companies. According to other studies (Seegmüller, 2008) the corporate use of Wikis and Blogs is most frequent, which is reflected in our results for the R\&D department as well.

The assumed objectives of a corporate use of Web 2.0 tools in order to support product development have been confirmed by most of the respondents. The focus however varies with the use of specific applications. Overall, the highest agreement has been reached regarding the target of collecting corporate knowledge, which is also consistent with the identified suitability for knowledge management in current literature (Buhl, 2008). The study shows that this objective is mostly connected with the use of Blogs and Twitter. If companies want their employees to externalize their tacit knowledge, Blogs might be suitable applications because of the various posts being characterized by personal experience and knowledge of the authors.

In this context, it is interesting to compare the goals of the corporate use with the content of corporate Web 2.0 applications. This can give deeper insights in the real use of Web 2.0 tools in daily business. Especially the goal of building up a glossary is least mentioned, but in contrast to that, most of the respondents report that a high percentage of the content is only informative in the sense of a reference book. A possible explanation could be the imbalance between active authors and passive users (Töpfer et al., 2008). The first group contributes actively in creating and editing content, following the principle of participation, whereas the second group only participates passively as consumers of content. This would explain the perception of the offered Web 2.0 applications being a reference book. Companies or at least managers should encourage their employees to contribute actively to create content of the applications and there should be a clear commitment to the use of such applications in daily business on both sides, the (top-)management and the employees. Nevertheless, the employees should get involved voluntarily and not be forced to do so. 
Concerning the objectives of the corporate use of Social Networks, it is of further interest, that the most often identified target is to bring in new ideas into the company. It can be assumed, that the potentials resulting of personal networking are of higher importance compared to the possibility of writing and maybe discussing in detail about ideas for example in Blogs or Wikis. The respondents seem to prefer getting in contact via Social Networks and perhaps discussing their ideas "offline".

Regarding corporate use of Twitter or comparable applications, we can emphasize that this kind of application is less used in companies. This might be a result of the novelty of this class of applications and the yet insufficient diffusion in corporate use. So, unfortunately, only less significant conclusions can be drawn: In best case, first tendencies can be observed, indicating the potentials that could possibly be realized due to future use of this kind of applications in R\&D. For instance, companies try to use Twitter in order to bring new ideas into the company and to contribute to higher relevance and dynamic. For this reason, companies ought to monitor the evolutions concerning Twitter and the related applications in order to increase their chances to identify new trends and to correctly estimate the current potentials.

Within this current study, we could show that there is a relation between the duration of usage and the frequency of use in daily business. We assume the longer the duration, the higher the frequency of use of Web 2.0 applications for daily business purposes, as it is clearly visible in the case of Wikis. This suggests that Wikis can be established very well at the workplace. A reason for that might be, that Wikis are worked on basically by a large group of users and because of that, network effects can be realized. In general, it can be shown, that the acceptance of Web 2.0 applications increases by time and has led to high acceptance after four years. Furthermore the study points out, that - after some uncertainties in the beginning of corporate use of Web 2.0 applications, which can be characterized by seldom or occasional use - the so-called critical mass of users must have been reached because of the applications being an essential part of daily business after this period. According to our previous empirical results, it might not only be the critical mass, but the personal benefits employees can realize by using Web 2.0 applications. So the use and the acceptance of such applications is positively influenced by employees having some sense of achievement, for example savings of time or identification of previously unknown experts on certain topics.

In addition, a correlation between quality assurance and evaluation of quality within the different tools can be assumed. A possible reason for some respondents to escape into "variation of quality in dependence of use case" could be that there is no common definition of quality or quality criteria, since the evaluation of quality highly depends on the subjective perception of the content, which is influenced by personal experience and expectations. Secondly, it could also be concluded that there is no evaluation of quality by users at all. Some companies report that authors, who are aware of the fact, that the created content is visible by a broader audience in the department or even the company, feel obliged to ensure the quality of their contributions. Finally, another explanation for this phenomenon could be the conscious decision of companies to motivate employees to participate in creating content and not discourage them by some kind of "quality control" (Ernst, 2009). So managers should clearly define some use cases, in which they want such applications to be used and have clear commitment to the use of Web 2.0 applications in daily business.

Through the use of Web 2.0 applications within the surveyed companies, first tendencies of substitution of established applications can be observed. The substitution of telephone calls and e-mail can be explained with the availability of the content for a greater audience. Other employees can get some basic information before contacting the authors directly at all. Furthermore, we assume that a part of the communication is done by Instant Messaging or Social Networks, because of their high diffusion rates, instead of using telephone or e-mail. This will lead to faster and more efficient processes in R\&D because of shorter ways of communication and shorter response time.

Concerning the impact of corporate use of Web 2.0 applications on innovation management, it has not been possible to make a significant statement yet. In our study, there are some tendencies visible, which suggest a positive influence at least in the future. Our respondents do experience some positive influence by the use of Web 2.0 applications, which becomes obvious through the increasing number of new ideas and of transparency in discussing them. Furthermore, a corresponding tendency can be observed, that the speed of innovation is felt higher since Web 2.0 tools have been used. However, to make significant statements, the applications seem not to having been used long enough. But companies using Web 2.0 applications with the goal of increasing the amount of ideas should be prepared to handle the evaluation and selection of the emerging ideas (Voigt et al., 2010).

\section{Conclusion and further research}

In our study - based on a literature review and an explorative pre-research - we could show that corporate use of Web 2.0 applications can realize several potentials concerning the generation and the exchange of knowledge within companies. Our empirical quantitative research of the status quo of corporate use of Web 2.0 applications can close the gap of existing studies, which do not focus on frequency and usage of such tools in R\&D. Based on the evaluation of quality of the content and the frequency of use, it has been pointed out that the use of Web 2.0 applications and the therewith exchanged knowledge are important for daily business and so for maintenance of business activity. Concerning support of the emergence of innovations stimulated by Web 2.0 applications, we have found some tendencies, which indicate a positive influence. So are the increase of the number of new ideas and the higher transparency in discussing them through the use of Web 2.0 tools. Some statements of our study are only of limited significance due to the small data base concerning applications like Social Networks or Twitter or comparable applications. It remains to be analyzed, how corporate use of these applications will develop in the future. In a few 
years, there might be the chance for further research tailored to Social Networks and Twitter or comparable applications. In this context, it is of particular interest to investigate the presence of tendencies of substitution among the Web 2.0 applications themselves, for example if microblogging has some influence on the use of Blogs or Instant Messaging. Furthermore, it could be analyzed, which factors influence the motivation of employees to participate. Our findings show clearly the use in daily business and it can be assumed, that one reason is the relevance of the content. So far, there are no further significant insights of motivation factors of employees in this field. Based on the findings of our research, further research could gain clues on evaluating for example the question which application fits best on which value-added step in order to support companies in implementing successfully Web 2.0 applications along their value chain.

\section{Nomenclature}

IJEST International Journal of Engineering, Sciences and Technology

R\&D research and development

$\mathrm{n} \quad$ universe based on the current question

$\mathrm{N} \quad$ universe of the survey

\section{Acknowledgement}

Special thanks goes to Dr. S. John (Dipl.-Kfr.), who has been working as Senior Research and Teaching Assistant at the University of Erlangen-Nuremberg and received her PhD in 2010. Her feedback and her support have been very worthy during the realization of this study.

\section{References}

Albers, S. 2007. Methodik der empirischen Forschung, $2^{\text {nd }}$ ed. Wiesbaden.

Alby, T. 2007. Web 2.0 - Konzepte, Anwendungen, Technologien, München.

Bach, N., Homp, C. 1998. Objekte und Instrumente des Wissensmanagements. Zeitschrift Führung + Organisation (zfo), Vol. 67, No. 3, pp. 139-146.

Bächle, M. 2008. Ökonomische Perspektiven des Web 2.0 - Open Innovation, Social Communities und Enterprise 2.0. Wirtschaftsinformatik (WI), Vol. 50, No. 2, pp. 129-132.

Back, A., Gronau, N., Tochtermann, K. 2008. Web 2.0 in der Unternehmenspraxis - Grundlagen, Fallstudien und Trends zum Einsatz von Social Software, München.

Beck, A. 2007. Web 2.0: Konzepte, Technologien, Anwendungen. Beck, A., Möhrike, M., Sauerburger, H. (ed.). Web 2.0, HMD Praxis der Wirtschaftsinformatik, No. 255, pp. 5-16.

Berekoven, L., Eckert, W., Ellenrieder, P. 2001. Marktforschung - Methodische Grundlagen und praktische Anwendung, Wiesbaden.

Berkhout, A.J., Hartmann, D., van der Duin, P., Ortt, R. 2006. Innovating the Innovation Process. International Journal of Technology Management, Vol. 34, Nos. 3/4, pp. 390-404.

Berndt, R. 1996. Marketing 1 - Käuferverhalten, Marktforschung und Marketing-Prognosen, Berlin et al.

Bilgram, V., Brem, A., Voigt, K.-I. 2008. User-centric innovations in new product development - systematic identification of lead users harnessing interactive and collaborative online-tools, in: International Journal of Innovation Management, Vol. 12, No. 3, pp. 419-458.

Böhler, H. 1992. Marktforschung, Stuttgart.

Bohl, O., Manouchehri, S. 2008. Vertrauensaspekte beim Einsatz von Social Software. von Krotzfleisch, H.F.O., Bohl, O. (ed.). Wissen, Vernetzung, Virtualisierung, Köln, pp. 449-460.

Boos, M., Rack, O., Schauenburg, B. 2008. Wissenskommunikation in computergestützten Gruppen - Theoretischer Hintergrund und empirische Befunde. Information Wissenschaft \& Praxis, Vol. 59, No. 1, pp. 41-48.

Borchert, J.E., Hagenhoff, S. 2004. Anforderungen an Instrumente des operativen Innovationsmanagements in Netzwerken, Göttingen.

Brem, A., Voigt, K.-I. 2009. Integration of Market Pull and Technology Push in the Corporate Front End and Innovation Management - Insights from the German Software Industry. Technovation - The International Journal of Technological Innovation, Entrepreneurship and Technology Management, Vol. 29, No. 5, pp. 351-367.

Bughin, J., Manyika, J., Miller, A. 2008. McKinsey Global Survey Results - Building the Web 2.0 Enterprise, Brüssel San Francisco.

Bughin, J., Chui, M., Miller A. 2009. How companies are benefitting from Web 2.0. McKinsey Global Survey Results, pp. 10-17.

Buhl, H.U. 2008. Online-Communitys - der Weg zur Gruppenintelligenz oder zur Gruppenignoranz und kollektiven Verdummung?. Wirtschaftsinformatik (WI), Vol. 50, No. 2, pp. 81-84. 
Bullinger, A.C., Hallerstede, S.H., Renken, U., Soeldner, J.-H., Möslein, K.M. 2010. Towards Research Collaboration - A Taxonomy of Social Research Network Sites. Proceedings of the Sixteenth Americas Conference on Information Systems, Lima, August 2010.

Carr, N.G. 2004. Does IT matter?, Boston.

Cook, N. 2008. Enterprise 2.0 - How Social Software Will Change the Future of Work, London.

Ehrlenspiel, K. 2007. Integrierte Produktentwicklung - Denkabläufe, Methodeneinsatz, Zusammenarbeit, $4^{\text {th }}$ ed., München Wien.

Ernst, M. 2009. Unpublished working paper at the Chair of Industrial Management at the University of Erlangen-Nuremberg.

Ganswindt, T. 2006. Treibstoff der Wirtschaft. Dietrich, L.; Schirra, W. Innovationen durch IT - Erfolgsbeispiele aus der Praxis Produkte - Prozesse - Geschäftsmodelle, Heidelberg, pp. 57-64.

Geulen, E. 2006. Innovationsstrategie im Wandel der Zeit. Dietrich, L.; Schirra, W. (ed.). Innovationen durch IT - Erfolgsbeispiele aus der Praxis - Produkte - Prozesse - Geschäftsmodelle, Heidelberg, pp. 37-56.

Gölz, S. 2007. Wissensmanagement 2.0 - Projekterfahrungen der OSCAR GmbH. OSCAR.trends Magazin, No. 2, pp. 28-32.

Gouthier, M.H.J. Hippner, H. Web 2.0 - Anwendungen als Corporate Social Software. Hass, B.H., Walsh, G., Kilian, T. (ed.). Web 2.0 - Neue Perspektiven für Marketing und Medien, Berlin Heidelberg, pp. 91-100.

Grossmann, M., McCarthy, R.V. Web 2.0: Is the Enterprise Ready for the Adventure?. Issues in Information Systems, Vol. 8, No. 2, pp. 180-185.

Hage, S. 2006. Der Web-Meister. http://www.manager-magazin.de/it/artikel/0,2828,449911,00.html, viewed 2009-04-08.

Hideyuki, F. 2007. "InnovationCafe", an In-house Social Network Service (SNS) Used in NEC. NEC Technical Journal, Vol. 2, No. 2, pp. 63-67.

Hirsch, C., Hosking, J., Grundy, J., Chaffe, T., MacDonald, D., Halytskyy, Y. The Visual Wiki: A New Metaphor for Knowledge Access and Management, Proceedings of the $42^{\text {nd }}$ Hawaii International Conference on System Sciences, 2009.

Homburg, Ch., Krohmer, H. 2006. Grundlagen des Marketingmanagements - Einführung in Strategie, Instrumente, Umsetzung und Unternehmensführung, Wiesbaden.

Koch, M., Richter, A. 2007. Enterprise 2.0 - Planung, Einführung und erfolgreicher Einsatz von Social Software in Unternehmen, München.

Koen, P., Ajamian, G., Burkart, R., Clamen, A., Davidson, J., D’Amore, R., Elkins, C., Herald, K., Incorvia, M., Johnson, A., Karol, R., Seibert, R., Slavejkov, A., Wagner, K. 2002. Providing Clarity and a Common Language to the „Fuzzy Front End“. Research and Technology Management, Vol. 44, No. 2, pp. 46-55.

Komus, A., Wauch, F. 2008. Wikimanagement - Was Unternehmen von Social Software und Web 2.0 lernen können, München.

Krause, F.-L., Franke, H.-J., Gausemeier, J. (ed.) 2007. Innovationspotenziale in der Produktentwicklung, München Wien.

Kranz, J., Janello, C., Picot, A. 2009. Die Rolle von Web 2.0-Prinzipien im Innovationsprozess. Information Management und Consulting, Vol. 24, No. 2, pp. 9-47.

Lochmaier, L. 2007. Führung und der intelligente Schwarm. http://www.manager-magazin.de/it/cio-spezial/0,2828,513549, 00.html, 2007-10-30, viewed 2009-04-08.

Madhavan, R., Grover, R. 1998. From Embedded Knowledge to Embodied Knowledge: New Product Development as Knowledge Management. Journal of Marketing, Vol. 62, pp. 1-12.

McAfee, A.P. 2006. Enterprise 2.0: The Dawn of Emergent Collaboration. MITSloan Management Review, Vol. 47 (2006) No. 3, (Reprint Number 47306), pp. 21-28.

McAfee, A.P. (a) 2009. Enterprise 2.0: new collaborative tools for your organization's toughest challenges, Boston.

McAfee, A.P. (b) 2009. Shattering the Myths About Enterprise 2.0. Harvard Business Review, November 2009, pp. 1-6.

Newman, A.C., Thomas, J.G. 2009. Enterprise 2.0 Implementation, McGraw-Hill.

N.N.(a). 2006. Web 2.0: Kooperieren, nicht kontrollieren. Computerwoche, 2006-12-20, p. 21.

N.N.(b). 2006. Vom Web 2.0 zu Enterprise 2.0. Computerwoche, 2006-07-07, pp. 26-27.

Langham, M. 2007. Enterprise 2.0. Entwickler Magazin, No. 1, pp. 131-136.

Lattemann, C., Stieglitz, S., Kupke, S. 2009. Deutsche Unternehmen auf dem Weg zum Web 2.0?. HMD Praxis der Wirtschaftsinformatik, No. 267, pp. 18-26.

Neyer, A.-K., Doll, B., Möslein, K.M. 2008. Prototyping als Instrument der Innovationskommunikation. Zeitschrift Führung + Organisation (zfo), Vol. 77, No. 4, pp. 210-216.

Reichart, S., Reichart, M. 2006. Erfolgsfaktor Innovationsprozess bei der Siemens AG. Zeitschrift Führung + Organisation (zfo), Vol. 75, No. 3, pp. 163-168.

Reinhold, D., Michel, K.-U. 2007. Wissensmanagement vs. Competitive Intelligence - Die Notwendigkeit einer Symbiose beider Disziplinen für die Schaffung von strategischen Wettbewerbsvorteilen. Information Wissenschaft \& Praxis, Vol. 58, No. 6-7, pp. 327-332.

Sandkuhl, K. 2005. Wissensportale - Merkmale, Architekturen und Perspektiven. Informatik Spektrum, Vol. 28, No. 3, pp. 193201.

Schachner, W., Tochtermann, K., Giesswein, M. 2009. Quo vadis Web 2.0?, in: Wissensmanagement - Das Magazin für Führungskräfte, Vol. 11, No. 2, pp. 20-24. 
Seegmüller, K. 2008. Wissen teilen ist nicht nur innerhalb des Unternehmens sinnvoll, sondern auch zwischen Kunden und Lieferanten - Enterprise 2.0 braucht Chef 2.0. Computer Zeitung, No. 47.

Seipel, C., Rieker, P. 2003. Integrative Sozialforschung - Konzepte und Methoden der qualitativen und quantitativen empirischen Forschung, Weinheim München.

Tapscott, D., Williams, A.D. 2006. Wikinomics: How Mass Collaboration Changes Everything, Portfolio.

Töpfer, A., Silbermann, S., William, R. 2008. Die Rolle des Web 2.0 im CRM - Wie kann durch interaktives Internet die Beziehung zum Kunden verstärkt und verbessert werden?. Töpfer, A. (ed.) Handbuch Kundenmanagement - Anforderungen, Prozesse, Zufriedenheit, Bindung und Wert von Kunden, $3^{\text {rd }}$ ed., Heidelberg.

Vahs, D., Burmester, R., 2005. Innovationsmanagement - Von der Produktidee zur erfolgreichen Vermarktung, $3^{\text {rd }}$ Ed., Stuttgart.

Voigt, K.-I. 1998. Strategien im Zeitwettbewerb - Optionen für Technologiemanagement und Marketing, Wiesbaden.

Voigt, K.-I., Ernst, M., Schindler, M. 2010. Strategic Foresight - A Web 2.0 Based Concept for the Integration of Foresight

Activities into Innovation Management, $5^{\text {th }}$ International Innovation Lab Conference, Nuremberg, October.

von Krotzfleisch, H., Mergel, I., Manouchehri, S., Schaarschmidt, M. 2008. Corporate Web 2.0 Applications. Hass, B. H., Walsh,

G., Kilian, T. (ed.): Web 2.0 - Neue Perspektiven für Marketing und Medien, Berlin Heidelberg, pp.73-87.

Weber, M. 2008. Enterprise 2.0 - Analyse zu Stand und Perspektiven in der deutschen Wirtschaft, Berlin.

Zimmermann, H.-D. 2007. Web 2.0 und seine Bedeutung für die Unternehmen. Innovation Management, No. 1, pp. 42-45.

\section{Biographical notes}

Prof. Dr. Kai-Ingo Voigt is a Full Professor at the Friedrich-Alexander University of Erlangen-Nuremberg, Germany, where he has held the Chair of Industrial Management since 1998. He received his PhD in 1991 from the University of Hamburg. His current research focuses are Strategic Management, Innovation and Technology Management, Management of (Industrial) Services and Production and Operations Management.

Dipl.-Wirtsch.-Ing. Markus Ernst received his diploma degree in Industrial Engineering from the University of Erlangen-Nuremberg in 2009. Since then, he has been working as Senior Research and Teaching Assistant at the University of Erlangen-Nuremberg. His research interests are Technology and Innovation Management as well as Enterprise 2.0.

Received June 2010

Accepted September 2010

Final acceptance in revised form November 2010 